Página Web 1 de 1

LWWOnline | LOGIN | eALERTS | REGISTER | CUSTOMER SUPPORT

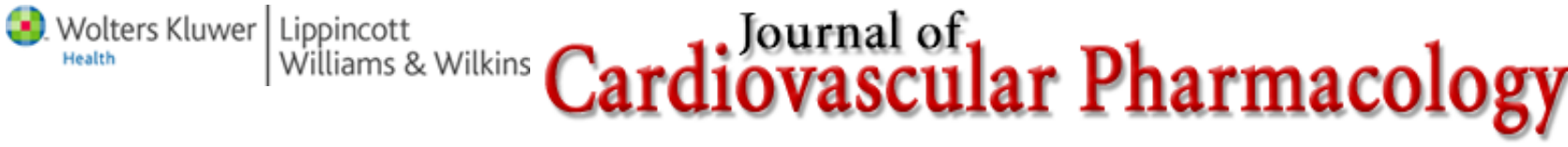

Home Search Current Issue Archive

Return to the search results

ARTICLE LINKS:

Fulltext | PDF (288 K)

\title{
Effect of Saline Load and Metoclopramide on the Renal Dopaminergic System in Patients with Heart Failure and Healthy Controls.
}

\section{Original Article}

Journal of Cardiovascular Pharmacology. 45(3):197-203, March 2005.

Alvelos, Margarida MD *; Ferreira, Antonio MD, PhD *+; Bettencourt, Paulo MD, PhD *+; Pimenta, Joana MD *; Azevedo, Ana MD *; Serrao, Paula BSc ++; Rocha-Goncalves, Francisco MD, PhD *

[S]; Soares-da-Silva, Patricio MD, PhD ++

\begin{abstract}
:
Dopamine of renal origin has natriuretic/diuretic actions by activating D1-like receptors of the nephron. Saline load increases renal dopamine production and natriuresis in healthy subjects, and, under these conditions, the activation of D2-like receptors also produces natriuresis/diuresis. Metoclopramide is a D2-like receptor antagonist. Patients with heart failure (HF) have an increased renal dopamine-synthesizing efficiency. However, the effect of salt loading was not explored in HF. We hypothesized that HF patients respond to salt loading with increased production of renal dopamine and that metoclopramide antagonizes this response. This was a randomized, controlled, crossover study exploring the effect of $\mathrm{NaCl}$ and metoclopramide on renal dopaminergic, sympathetic, renin-angiotensin-aldosterone, and arginine-vasopressin (AVP) systems activity on sodium handling in $9 \mathrm{HF}$ patients and 9 controls. $\mathrm{NaCl}$ markedly increased renal dopamine production and natriuresis in both groups. Metoclopramide blunted these responses in HF patients but not in controls. $\mathrm{NaCl}$ decreased renin and aldosterone plasma levels in controls but not in $\mathrm{HF}$ patients. In these patients B-type natriuretic peptide (BNP) levels increased, but AVP was not affected. HF patients respond to salt loading with increased natriuresis. However, the mechanisms for this response are different from those found in healthy subjects. Metoclopramide has antinatriuretic effects only in HF patients.
\end{abstract}

(C) 2005 Lippincott Williams \& Wilkins, Inc.

Copyright $\odot$ 2007, Lippincott Williams \& Wilkins. All rights reserved

Published by Lippincott Williams \& Wilkins.

Copyright/Disclaimer Notice • Privacy Policy

XML Subscribe to our RSS feed

utrdc-pt01

Release 4.7.0 